\title{
List of exhibits
}

2.1 Employment in the foundational economy (FE) in Germany, Italy and the UK in 2016/17

page 24

2.2a Employment in Liverpool city region in 2016

2.2b Employment in London in $2016 \quad 26$

2.3 Average weekly household expenditure in the EU 28 countries in 2015

3.1 UK equity withdrawal, 1970-2016 56

3.2 UK public sector debt as a percentage of GDP, 1900-2017

3.3 UK non-retired households receiving more in benefits than paid in taxes, 1977-2015/16

3.4 UK residential care costs based on different return on capital assumptions

3.5 Who gets what from the sale of a litre of milk in the UK, 1996-2011

3.6 The UK West Coast Trains operating franchise: income, payments and extraction, 1997-2012

3.7 The UK West Coast Trains operating franchise: summary of subsidies, profit and dividends, 1997-2012

5.1 Populus survey of UK service priorities 
5.2 Distribution of UK household net wealth, 2012-14

5.3 Local revenue raised through local taxes, 2012 